\title{
Karakterisasi Uwi-Uwian (Dioscorea spp) Dari Banjarnegara Berdasarkan Penanda Morfologi
}

\author{
Susy Ika Pertiwa, Jumari dan Erry Wiryani \\ Laboratorium Ekologi dan Biosistematik \\ Departemen Biologi Fakultas Sains dan Matematika, Universitas Diponegoro, Semarang \\ Jln Prof. Soedarto, SH,Semarang, \\ e-mail : susyikaa@gmail.com
}

\begin{abstract}
The diversity of Dioscorea spp. both inter-species and intra-species are spreaded in several areas in Central Java, including Banjarnegara. Dioscorea is a plant that has the potentials to be developed and cultivated. The purposes of this reasearch are to identify the species, characterize the morphological characters (stem, leaf, and tuber) of eight varians Dioscorea spp from Banjarnegara. The sample used in this reasearch are the eight varians of Dioscorea spp from Banjarnegara. The Identification was done by using a identification keys. Characterization of morphological characters was done by using the guidebook of Descriptor for Yam. The results showed that eight cultivars of Dioscorea spp are grouped into two types: Dioscorea alata and Dioscorea esculenta. Dioscorea alata has a stem which rotate the to the right, rectangular shaped of stem, it's has wing and doesn't have a spin, elongated heart-shaped leaves, oval-oblong and round shaped tuber. Dioscorea esculenta has a stem which rotate to the left, rounded shaped of stem, it has not wing but spiked, dilated heart-shaped leaf, and oval shape tuber.
\end{abstract}

Keywords: Dioscorea spp, identifikasi, characteristic, morphology,

\begin{abstract}
Abstrak
Keanekaragaman Dioscorea spp. baik inter spesies maupun intra spesies tersebar di beberapa daerah di Jawa Tengah, termasuk di Banjarnegara. Dioscorea merupakan salah satu tumbuhan yang berpotensi untuk dikembangkan dan dibudidayakan. Tujuan penelitian ini adalah untuk mengidentifikasi jenis, mengkarakterisasi morfologi batang, daun, dan umbi beberapa varian Dioscorea spp dari Banjarnegara. Sampel yang digunakan untuk penelitian ini adalah delapan varian Dioscorea spp dari Banjarnegara. Identifikasi dilakukan dengan menggunakan kunci identifikasi. Karakterisasi morfologi dilakukan dengan menggunakan buku panduan. Hasil identifikasi menunjukkan bahwa delapan varian Dioscorea spp teridentifikasi menjadi dua jenis yaitu Dioscorea alata dan Dioscorea esculenta. D. alata memiliki karakter arah putaran batang ke kanan, bentuk batang bersegi, batang bersayap, tidak berduri, daun berbentuk jantung memanjang, umbi berbentuk oval-oblong dan bulat. D.esculenta memiliki arah putaran batang ke kiri, batang berbentuk membulat, tidak bersayap, berduri, bentuk daun jantung melebar, bentuk umbi oval.
\end{abstract}

Kata Kunci: Dioscorea spp, identification, karakteristik, morfologi, 


\section{PENDAHULUAN}

Indonesia merupakan negara yang memiliki keanekaragaman hayati yang sangat tinggi. Berbagai jenis tanaman tersebar di Indonesia, termasuk tanaman pangan, namun sebagian besar masyarakat Indonesia hanya mengandalkan beras sebagai sumber pangan utamanya. Hal ini dapat menimbulkan masalah bagi ketahanan pangan nasional,. Oleh karena itu upaya pengembangan pangan sumber karbohidrat alternatif dari jenis tanaman lain perlu dilakukan. Salah satu tanaman pangan lokal yang dapat dikembangkan sebagai sumber karbohidrat, antara lain yaitu tanaman umbi-umbian.

Umbi-umbian mempunyai keunggulan yakni mempunyai kandungan karbohidrat tinggi sehingga bermanfaat sebagai sumber tenaga. Salah satu umbi-umbian yang kaya akan karbohidrat adalah Dioscorea spp. Tercatat sekitar 50-60 spesies Dioscorea yang dibudidayakan dan telah dimanfaatkan sebagai tanaman pangan dan obat. Dioscorea spp (uwi) merupakan salah satu tanaman pangan berkarbohidrat tinggi, mengandung $63.31 \%$ pati, $6.66 \%$ protein dan $0.64 \%$ lemak (Ariesta, 2004).

Pemanfaatan dan konsumsi umbi uwi di lingkungan masyarakat masih sangat rendah. Salah satu penyebab rendahnya konsumsi umbi uwi adalah rendahnya tingkat produksi dan ketersediaannya di pasar. Rendahnya tingkat produksi umbi uwi dapat disebabkan karena rendahnya minat masyarakat untuk membudidayakan umbi uwi. Umbi uwi dapat dipanen pada umur 8-9 bulan setelah masa tanam dan mengalami istirahat selama 1-6 bulan pada musim kemarau (Hanarida dkk, 2005).

Dioscorea spp memiliki banyak varietas yang berpotensi untuk dibudidayakan. Keanekaragaman Dioscorea spp baik antar spesies maupun intraspesies yang belum diketahui tersebar di beberapa daerah di Jawa Tengah, termasuk di Banjarnegara. Hasil penelitian sebelumnya oleh Jumari dan Suedy (2017) telah didapat 50 varian Dioscorea di Jawa Tengah. Sebanyak delapan varian didapatkan dari Banjarnegara dan sudah ditanam di hutan Edukasi Universitas Dioponegoro. Varian tersebut belum dikarakterisasi secara utuh bagian daun, batang dan umbinya. Karakterisasi bagian-bagian tersebut sangat diperlukan untuk mengetahui ciri dan karakter spesifik yang dimiliki oleh tiap jenis uwi. Penelitian ini bertujuan untuk memberikan informasi tentang jenis, karakteristik morfologi bagian daun, batang, dan umbi beberapa varian Dioscorea spp dari Banjarnegara.

\section{BAHAN DAN METODE}

Tempat dan Waktu: Penelitian dilaksanakan pada bulan Januari 2017. Lokasi penelitian dilakukan di Hutan Edukasi Universitas Diponegoro dan di Laboratorium Ekologi dan Biosistematika.

Alat dan Bahan: Alat yang digunakan pada penelitian ini berupa, penggaris, buku panduan, Descriptors for Yam (Dioscorea spp), kunci identifikasi, cutter, pisau, kamera, alat tulis, label, solatip, cangkul, tali, lembar form karakterisasi uwi, buku catatan, tissue, dan plastik. Bahan yang digunakan pada penelitian ini adalah delapan varian Dioscorea spp dari Banjarnegara yaitu uwi pandan, uwi bangkulit, uwi wulung, uwi putih, gembili pak yasir (kecil), gembili pak yasir, gembili biasa, dan kemarung yang berjumlah 24 sampel (Tiga sampel per varian).

\section{Identifikasi Dioscorea spp}

Identifikasi jenis Dioscorea spp menggunakan kunci identifikasi dalam buku $A$ Practical Guide to Identifying Yams The Main Species of Dioscorea in the Pacific Islands.

Karakterisasi morfologi batang daun dan umbi Dioscorea spp

Karakterisasi morfologi batang daun Dioscorea spp dilakukan secara langsung pada delapan varian Dioscorea spp yang sudah ditanam di Hutan Edukasi. Pengamatan ciri umbi dilakukan pada umbi hasil koleksi dari Banjarnegara. Pengamatan Dioscorea spp mengacu pada buku panduan Descriptors for Yam (Dioscorea spp.)

\section{Analisis Data}

Data karakteristik morfologi batang, daun, dan umbi Dioscorea spp dari Banjarnegara ditabulasikan. Data dianalisis secara deskriptif.

\section{HASIL DAN PEMBAHASAN Identifikasi Dioscorea spp}

Berdasarkan hasil pengamatan delapan varian Dioscorea spp asal Banjarnegara hasil koleksi dan yang telah ditanam kembali di Hutan Edukasi Universitas Diponegoro Semarang berhasil diidentifikasi menjadi dua jenis yaitu Dioscorea alata dan Dioscorea esculenta. Hasil identifikasi jenis Dioscorea spp dari Banjarnegara disajikan dalam Tabel 1.

Hasil pengamatan menunjukkan bahwa uwi pandan, uwi wulung, uwi bangkulit, dan uwi putih memiliki ciri arah putaran batang ke kanan. Batang bagian atas dan bawah memiliki sayap dan tidak berduri. Daunnya berbentuk jantung memanjang. Umumnya varian-varian ini tidak memiliki umbi udara. Berdasarkan kesamaan karakteristik tersebut, keempat varian ini diidentifikasi sebagai jenis $D$. alat 
Tabel .1. Hasil identifikasi jenis Dioscorea spp

\begin{tabular}{|c|c|c|c|c|c|c|c|}
\hline \multirow[b]{2}{*}{ No } & \multirow[b]{2}{*}{ Nama lokal } & \multirow[b]{2}{*}{ Asal } & \multicolumn{5}{|c|}{ Karakter } \\
\hline & & & $\begin{array}{l}\text { arah } \\
\text { putaran } \\
\text { batang }\end{array}$ & $\begin{array}{l}\text { sayap } \\
\text { batang }\end{array}$ & $\begin{array}{l}\text { duri pada } \\
\text { batang }\end{array}$ & $\begin{array}{l}\text { ada tidak } \\
\text { nya umbi } \\
\text { udara }\end{array}$ & bentuk daun \\
\hline $\begin{array}{l}1 . \\
2 .\end{array}$ & Uwi Pandan & Gembongan Banjarnegara & kanan & ada & tidak ada & ada & $\begin{array}{l}\text { jantung } \\
\text { memanjang }\end{array}$ \\
\hline 3. & Uwi Wulung & $\begin{array}{l}\text { Bendoharjo } \\
\text { Banjarnegara }\end{array}$ & kanan. & ada & tidak ada & tidak ada & $\begin{array}{l}\text { jantung } \\
\text { memanjang }\end{array}$ \\
\hline 4 & Uwi Bangkulit & Bendoharjo, Banjarnegara & kanan & ada & tidak ada & tidak ada & $\begin{array}{l}\text { jantung } \\
\text { memanjang }\end{array}$ \\
\hline & Uwi Putih & Bendoharjo, Banjarnegara & kanan. & ada & tidak ada & tidak ada & $\begin{array}{l}\text { jantung } \\
\text { memanjang }\end{array}$ \\
\hline 5. & $\begin{array}{l}\text { Gembili Pak } \\
\text { Yasir (kecil) }\end{array}$ & $\begin{array}{l}\text { Gembongan, Sigaluh } \\
\text { Banjarnegara }\end{array}$ & kiri & tidak ada & ada sedikit & tidak ada & $\begin{array}{l}\text { jentıino melebar } \\
26\end{array}$ \\
\hline 6. & $\begin{array}{l}\text { Gembili Pak } \\
\text { Yasir }\end{array}$ & $\begin{array}{l}\text { Gembongan, Sigaluh } \\
\text { Banjarnegara }\end{array}$ & kiri & tidak ada & ada sedikit & tidak ada & $\mathrm{j} s \quad 2 \mathrm{O}$ telebar \\
\hline 7. & Gembili1 biasa & $\begin{array}{l}\text { Sigaluh } \\
\text { Banjarnegara }\end{array}$ & kiri & tidak ada & ada sedikit. & tidak ada & jantung melebar. \\
\hline 8. & Kemarung & $\begin{array}{l}\text { Punggelan BendoHarjo } \\
\text { Banjarnegara }\end{array}$ & Kiri & tidak ada & ada banyak & tidak ada & jantung melebar \\
\hline
\end{tabular}

Menurut Arifin (2008) varian Dioscorea spp yang termasuk ke dalam jenis $D$. alata adalah varian yang memiliki arah putaran batang ke kanan, batang bersegi empat atau lima, tidak memiliki duri dan batangnya bersayap dengan 4 sisi. Menurut Trustinah (2013) sayap berfungsi membantu batang menangkap objek untuk melilit. Umumnya jenis $D$. alata tidak memiliki umbi udara, namun umbi udara ditemukan pada uwi pandan. Uwi pandan tetap bisa digolongkan ke dalam jenis $D$. alata. Menurut Wilson et al., (1998) beberapa varian D. alata memiliki umbi udara..

Empat varian Dioscorea spp lainnya yaitu gembili pak yasir (kecil), gembili pak yasir, gembili biasa dan kemarung memiliki ciri arah putaran batang ke kiri. Umumnya varian ini tidak memiliki umbi udara. Batangnya berduri dan tidak bersayap. Berdasarkan hasil ciri yang dimiliki, gembili pak yasir (kecil), gembili pak yasir, gembili biasa dan kemarung diidentifikasi ke dalam kelompok $D$. esculenta.

Menurut Wilson et al.(1998) daun D. esculenta berbentuk jantung melebar. Gembili pak yasir (kecil), gembili pak yasir, gembili biasa dan kemarung memiliki daun berbentuk jantung melebar. Bentuk daun ini merupakan karakter $D$. esculenta yang paling mudah dibedakan dengan $D$. alata karena keduanya memiliki bentuk daun yang sangat berbeda. Perbedaan tersebu ditunjukkan pada Gambar 1

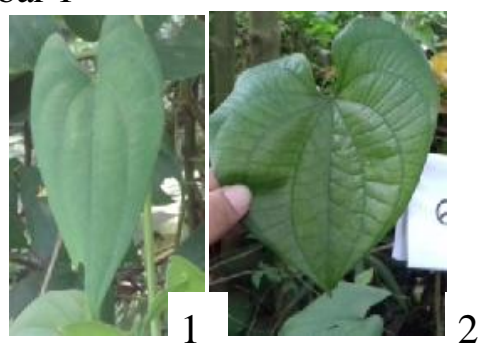

Gambar 1. Bentuk daun D.alata dan D.esculenta Keterangan: 1.Bentuk daun uwi putih jantung memanjang. 2. Bentuk daun gembili kemarung jantung melebar

\section{Karakterisasi Morfologi Batang dan Daun Dioscorea spp}

Berdasarkan penelitian diketahui terdapat keanekaragaman karakter antara varian-varian Dioscorea spp. Keanekaragaman ini terlihat dari beberapa karakter yang menunjukkan keunikan atau kekhasan yang dimiliki oleh masing-masing varian jenis $D$. alata dan jenis $D$. esculenta. Karakter-karakter tersebut disajikan pada Tabel 2. 
Tabel 2. Hasil karakterisasi morfologi batang dan daun delapan varian Dioscorea spp dari Banjarnegara

\begin{tabular}{|c|c|c|c|c|c|c|c|c|c|}
\hline \multirow{3}{*}{ No } & \multirow{3}{*}{ Karakteristik } & \multicolumn{8}{|c|}{ vallau } \\
\hline & & \multicolumn{4}{|c|}{ Dioscorea alata } & \multicolumn{4}{|c|}{ Dioscorea esculenta } \\
\hline & & Uyi Pandan & $\begin{array}{c}\text { Uni } \\
\text { Julung }\end{array}$ & $\begin{array}{c}\text { Uyi } \\
\text { Bangkulit }\end{array}$ & Uyi Putih & $\begin{array}{l}\text { Gembili } \\
\text { Pak Yasir } \\
\text { (kecil) }\end{array}$ & $\begin{array}{c}\text { Gembili } \\
\text { Pak Yasir }\end{array}$ & $\begin{array}{l}\text { Gembili } \\
\text { biasa }\end{array}$ & Kemarung \\
\hline 1. & Warna batang & hijau keunguan & hijau muda & hijau muda & hijau muda & hijau muda & hijau muda & hijau muda & hijau tua \\
\hline 2. & Tinggi batang (m) & 7 & 7 & 7 & 10 & 5 & 4 & 4 & 7 \\
\hline 3. & Diameter batang $(\mathrm{cm})$ & 0.8 & 0.4 & 0.7 & 0.8 & 0.4 & 0.3 & 0.2 & 0.4 \\
\hline 4. & Warna sayap & hijau keunguan & hijau & Hijau & $\begin{array}{l}\text { hijau } \\
\text { keunguan }\end{array}$ & tidak ada & tidak ada & tidak ada & tidak ada \\
\hline $\begin{array}{l}5 . \\
6 .\end{array}$ & $\begin{array}{l}\text { Panjang sayap (mm) } \\
\text { Ada tidaknya duri }\end{array}$ & $\begin{array}{l}1 \\
\text { tidak ada }\end{array}$ & $\begin{array}{l}1 \\
\text { tidak ada }\end{array}$ & $\begin{array}{l}1 \\
\text { tidak ada }\end{array}$ & $\begin{array}{l}1.5 \\
\text { tidak ada }\end{array}$ & $\begin{array}{l}\text { tidak ada } \\
\text { ada }\end{array}$ & $\begin{array}{l}\text { tidak ada } \\
\text { ada }\end{array}$ & $\begin{array}{l}\text { tidak ada } \\
\text { ada }\end{array}$ & $\begin{array}{l}\text { tidak ada } \\
\text { ada }\end{array}$ \\
\hline 7. & Bentuk duri & tidak ada & tidak ada & tidak ada & tidak ada & $\begin{array}{l}\text { bengkok ke } \\
\text { bawah }\end{array}$ & $\begin{array}{l}\text { bengkok ke } \\
\text { bawah }\end{array}$ & $\begin{array}{l}\text { bengkok ke } \\
\text { bawah }\end{array}$ & $\begin{array}{l}\text { bengkok ke } \\
\text { atas }\end{array}$ \\
\hline 8. & Panjang duri (mm) & tidak ada & tidak ada & tidak ada & tidak ada & 5 & 3 & 1 & 6 \\
\hline 9. & Warna daun & hijau tua & hijau tua & hijau tua & hijau tua & hijau tua & hijau muda & hijau tua & hijau tua \\
\hline 10. & Warna tepi daun & hiijau muda & hijau tua & hiijau muda & hiijau muda & hiijau muda & hiijau muda & hijau tua & hijau tua \\
\hline 11. & Warna tulang daun & Hijau & hijau tua & hijau & Hijau & hijau tua & hijau muda & hijau muda & hijau tua \\
\hline 12. & Warna tangkai daun & $\begin{array}{l}\text { hijau, } \\
\text { persimpangan } \\
\text { daun ungu }\end{array}$ & $\begin{array}{l}\text { hijau kedua } \\
\text { ujungnya } \\
\text { ungu }\end{array}$ & $\begin{array}{l}\text { hijau dasar } \\
\text { ungu }\end{array}$ & Hijau & hijau & Hijau & hijau & Hijau \\
\hline 13. & $\begin{array}{l}\text { Warna sayap tangkai } \\
\text { daun }\end{array}$ & hijau keunguan & hijau & $\begin{array}{l}\text { hijau } \\
\text { keunguan }\end{array}$ & Hijau & tidak ada & tidak ada & tidak ada & tidak ada \\
\hline 14. & Warna ujung daun & Merah & merah & hijau tua & Merah & hiijau muda & hiijau muda & hiijau muda & hiijau muda \\
\hline 15. & Undulasi pada daun & Sedikit & sedikit & banyak & Sedikit & tidak ada & tidak ada & tidak ada & tidak arla \\
\hline 16. & Rambut petiole & tidak ada & tidak ada & tidak ada & tidak ada & ada & tidak ada & tidak ada & 30 la \\
\hline 17. & Rambut daun & tidak ada & tidak ada & tidak ada & tidak ada & ada & tidak ada & tidak ada & SU la \\
\hline 18. & Panjang daun $(\mathrm{cm})$ & 12.8 & 17.2 & 14.5 & 15.9 & 8.2 & 9.2 & 7.8 & 8.3 \\
\hline 19. & Lebar daun $(\mathrm{cm})$ & 7.8 & 10 & 7.2 & 9.8 & 4.6 & 5.8 & 4 & 4.4 \\
\hline 20. & $\begin{array}{l}\text { Panjang ujung daun } \\
(\mathrm{cm})\end{array}$ & 1.1 & 1.6 & 1.5 & 1.3 & 0.7 & 0.8 & 0.4 & 0.3 \\
\hline 21. & Panjang petiole $(\mathrm{cm})$ & 10.6 & 13.3 & 15.6 & 8.6 & 7.3 & 10 & 4.9 & 9.3 \\
\hline
\end{tabular}

\section{Dioscorea alata}

Tinggi batang D. alata berkisar antara 7-10 m. Batang uwi putih tinggi batangnya mencapai $10 \mathrm{~m}$. Diameter batang D. alata berkisar antara $0.4 \mathrm{~cm}-0.8$ $\mathrm{cm}$. Varian D. alata yang memiliki batang berwarna hijau keunguan. Sesuai dengan pendapat Budoyo (2010) yang menyatakan batang D. alata umunya berwarna warna hijau atau keunguan. Warna batang varian $D$. alata dapat dilihat pada Gambar 2 .

Batang $D$. alata memiliki sayap dengan empat sisi. Sayap batang uwi pandan dan uwi putih berwarna hijau keunguan sedangkan uwi wulung dan uwi bangkulit sayapnya berwarna hijau. Panjang sayap uwi putih mencapai $1.5 \mathrm{~mm}$ sedangkan tiga varian lainnya memiliki panjang sayap $1 \mathrm{~mm}$.
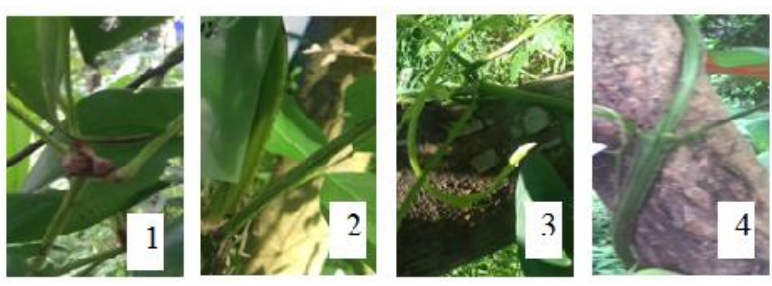

Gambar 2. Warna batang varian D. alata.

Keterangan: 1.Uwi pandan 2.Uwi wulung 3.Uwi bangkulit 4. Uwi putih

Daun varian D. alata merupakan daun tunggal dengan posisi daun berhadapan. Bentuk daun $D$. alata jantung memanjang. Bentuk daun varian D. alata dapat dilihat pada Gambar 3. Tepi daun varian $D$. alata rata dan ujung daunnya meruncing. Posisi daun terlebar berada di tengah. Jarak antar lobus sedang dan tidak terdapat rambut pada daun 

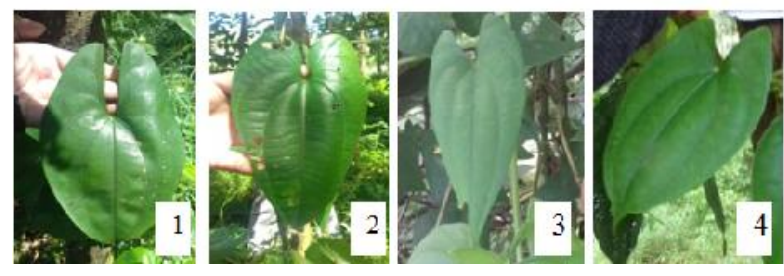

Gambar 3. Bentuk daun D. alata

Keterangan: 1. Uwi pandan 2. Uwi wulung 3. Uwi bangkulit 4. Uwi putih

Helai daun varian $D$. alata berwarna hijau tua. Tepi daun berwarna hijau muda dan tulang daunnya berwarna hijau Uwi wulung memiliki tepi daun dan tulang daun yang berwarna hijau tua. Ujung daun $D$. alata berwarna merah kecuali uwi bangkulit yang ujung daunnya berwarna hijau tua.

Tangkai daun uwi pandan berwarna hijau dengan persimpangan daun ungu. Tangkai daun uwi wulung berwarna hijau dan kedua ujungnya ungu. Uwi bangkulit memiliki tangkai daun yang berwarna hijau dasarnya ungu. Uwi putih memiliki tangkai daun yang berwarna hijau. Sayap tangkai daun uwi pandan dan uwi putih berwarna hijau keunguan sedangkan dua varian lainnya berwarna hijau.

Panjang daun D. alata berkisar antara 12.8 $17.2 \mathrm{~cm}$, lebar daun berkisar antara $7.2-10 \mathrm{~cm}$, panjang ujung daun antara $1.1-1.6 \mathrm{~cm}$ dan panjang petiolenya berkisar antara $8.6-15.6 \mathrm{~cm}$. Daun uwi wulung merupakan daun yang berukuran paling panjang dan paling lebar serta ujung daunnya paling panjang di antara varian D.alata lainnya. Menurut French (2006) ukuran daun D.alata berkisar antara panjang $10-30 \mathrm{~cm}$, dan lebar $5-20 \mathrm{~cm}$, tangkai daun antara $6-12 \mathrm{~cm}$.

\section{Diosocrea esculenta}

Varian D. esculenta memiliki batang dengan tinggi antara 4-7 m. Batang tertinggi dimiliki oleh kemarung. Diameter batang D. esculenta berkisar antara 0.2-0.4 cm. Menurut Richana (2004) D. esculenta tumbuh merambat dan dapat mencapai tinggi antara 3-5 m. Diameter batang D. esculenta berkisar antara $0.2-0.4 \mathrm{~cm}$. Batang umumnya berwarna hijau muda kecuali batang gembili kemarung yang berwarna hijau tua. Warna varian D. esculenta ditunjukkan pada Gambar .4.

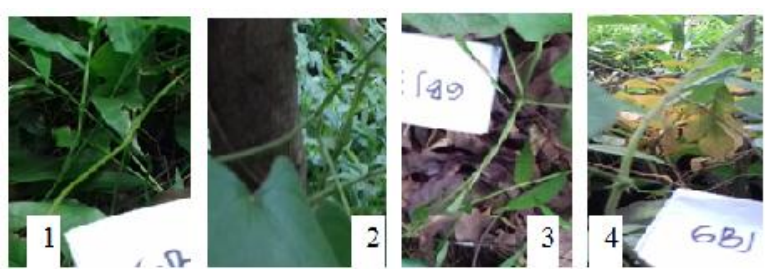

Gambar 4. Warna batang D.esculenta Keterangan: 1.Gembili pak yasir (kecil) 2.Gembili pak yasir 3.Gembili biasa 4. Kemarung

Duri pada batang varian $D$. esculenta berukuran 1-6 mm. Menurut Richana (2004) batang D. esculenta memiliki duri berukuran kecil. D. esculenta juga memiliki duri akar tetapi jumlahnya lebih sedikit daripada duri batangnya. Batang tiga varian $D$. esculenta memiliki duri yang bentuknya bengkok ke bawah. Satu varian lainnya yaitu Kemarung memiliki duri yang bengkok ke atas dan ukurannya paling besar diantara varian $D$. esculenta lainnya.

Daun varian $D$. esculenta tunggal dengan posisi daun berseling. Helai daun berbentuk jantung melebar. Bentuk daun varian D. esculenta ditunjukkan pada Gambar 4.5. Tepi daun $D$. esculenta rata dan ujung daunnya runcing. Jarak antar lobus sedang. Posisi bagian daun terlebar berada pada $1 / 3$ atas.
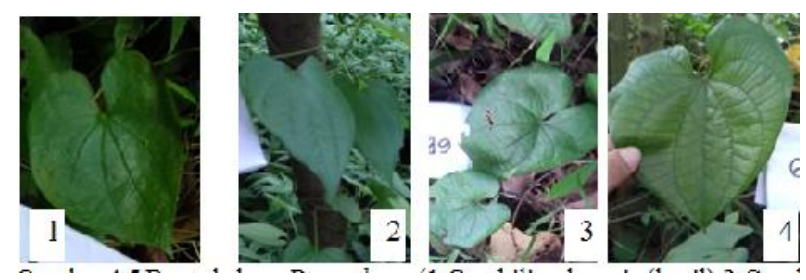

Gambar 5 Bentuk daun D.esculenta

Keterangan: 1.Gembili pak yasir (kecil) 2.Gembili pak yasir 3.Gembili biasa 4.Gembili kemarung

Daun D. esculenta umumnya berwarna hijau tua, kecuali varian gembili pk yasir yang daunnya berwarna hijau muda. Ujung daun $D$. esculenta juga berwarna hijau muda. Warna tepi daun dan tulang daun $D$. esculenta umumnya berwarna hijau tua atau hijau muda. Keempat varian memiliki warna tangkai daun yang seragam yaitu berwarna hijau. 
Karakterisasi Morfologi Umbi Dioscorea spp Hasil pengamatan delapan varian Dioscorea spp dari Banjarnegara menunjukkan keanekaragaman karakter morfologi pada umbinya. Hasil karakterisasi morfologi umbi delapan varian Dioscorea spp dari Banjarnegara disajikan pada Tabel 3

Tabel 3. Hasil karakterisasi morfologi umbi delapan varian Dioscorea spp dari Banjarnegara 禹

\begin{tabular}{|c|c|c|c|c|c|c|c|c|c|}
\hline \multirow{4}{*}{ No } & \multirow{4}{*}{ Karakteristik } & \multicolumn{8}{|c|}{ Varian } \\
\hline & & \multicolumn{4}{|c|}{ Dioscorea alata } & \multicolumn{4}{|c|}{ Dioscorea esculenta } \\
\hline & & Uyi Pandan & Uwi & Uyi & Uyi Putih & Gembili & Gembili & Gembili & Kemarung \\
\hline & & & Wulung & Bangkulit & & $\begin{array}{l}\text { Pak Yasir } \\
\text { (kecil) }\end{array}$ & Pak Yasir & biasa. & \\
\hline 1. & Jumlah umbi per 'hill' & $2-5$ & $2-5$ & $2-5$ & 1 & $>5$ & $>5$ & $>5$ & $>5$ \\
\hline 2. & $\begin{array}{l}\text { Kecenderungan umbi } \\
\text { bercabang }\end{array}$ & bercabang & bercabang & bercabang & bercabang & bercabang & bercabang & bercabang & bercabang \\
\hline 3. & Bentuk umbi & oval-oblong & oval-oblong & oval-oblong & bulat & oval & oval & Oval & oval \\
\hline 4. & Warna daging umbi & putih susu & $\begin{array}{l}\text { ungu dan } \\
\text { putih }\end{array}$ & putih susu & putih susu & putih susu & putih susu & putih susu & krem \\
\hline 5. & Tekstur daging umbi & halus & halus & kasar & halus & $\begin{array}{l}\text { halus (agak } \\
\text { kenyal) }\end{array}$ & sangat kasar & Halus & kasar \\
\hline 6. & Warna kulit luar umbi & coklat tua & coklat muda & coklat tua & coklat tua & coklat muda & coklat, muda & Krem & muda \\
\hline 7. & Warna kulit dalam umbi & coklat muda & ungu gelap & coklat muda & coklat muda & krem & krem & Krem & coklat \\
\hline 8. & Tekstur kulit luar umbi & halus & halus & halus & halus & halus & halus & sedikit kasar & kasar \\
\hline 9. & Ketebalan kulit & tipis & tipis & tebal & tipis & tipis & tipis & Tipis & tebal \\
\hline 10. & $\begin{array}{l}\text { Kerutan pada permukaan } \\
\text { umbi }\end{array}$ & tidak ada & tidak ada & tidak ada & tidak ada & sedikit & banyak & Banyak & banyak \\
\hline 11. & Retakan pada umbi & ada & ada & tidak ada & tidak ada & tidak ada & tidak ada & tidak ada & ada \\
\hline 12. & Akar pada umbi & banyak & sedikit & banyak & sedikit & sedikit & tidak ada & Sedikit & sedikit \\
\hline
\end{tabular}

\section{Dioscorea alata}

Umbi varian D.alata berbentuk oval-oblong, kecuali umbi uwi putih yang berbentuk bulat. Bentuk umbi varian D. alata ditunjukkan pada Gambar 6. Menurut French (2006) bentuk umbi (tuber) ada yang tidak beraturan, lonjong hingga bulat. Umbi $D$. alata umumnya bercabang, ada yang bercabang banyak ada pula yang bercabang sedikit. Berdasarkan pengamatan terdapat dua sampai lima umbi tiap cabangnya. Salah satu varian D. alata yaitu uwi putih bercabang banyak dengan satu umbi di setiap cabangnya.

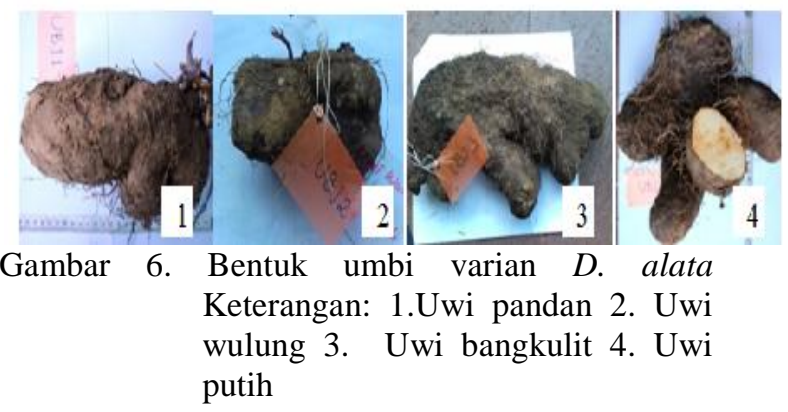

Varian D. alata umumnya memiliki kulit umbi tipis. Tekstur kulitnya halus. Kulit umbi $D$. alata tidak memiliki kerutan. Umumnya umbi varian $D$. alata memiliki akar pada kulitnya. Dua varian $D$. alata yaitu uwi pandan dan uwi wulung memiliki retakan pada kulitnya.

Kulit luar umbi varian $D$. alata rata-rata berwarna coklat tua. Kulit dalam umbi D. alata berwarna coklat muda. Satu varian $D$. alata yaitu uwi wulung memiliki kulit luar berwarna coklat muda dan kulit dalamnya berwarna coklat tua.

Daging umbi varian $D$. alata umumnya berwarna putih susu. Daging uwi wulung berwarna ungu dan putih. Hal ini sesuai dengan pendapat French (2006) yang menyatakan bahwa daging umbi (tuber) ada yang berwarna putih kuning kecokelatan hingga ungu Warna daging umbi varian D. alata ditunjukkan pada Gambar 7. Daging umbi varian $D$. alata bertekstur halus, kecuali uwi bangkulit yang daging umbinya betekstur kasar. 


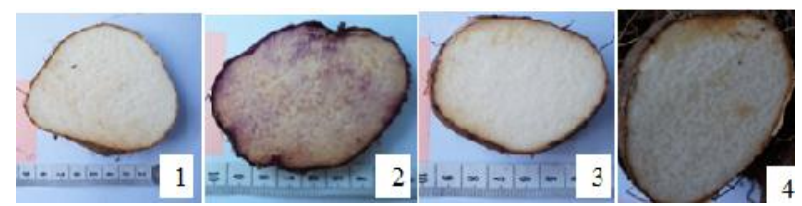

Gambar .7. Warna daging umbi varian D. alata Keterangan: 1. Uwi pandan 2. Uwi wulung 3.Uwi bangkulit 4.Uwi putih)

\section{Dioscorea esculenta}

Umbi varian $D$. esculenta berbentuk oval. Umbi bercabang dengan lebih dari lima umbi tiap cabangnya. Umbi D.esculenta umumnya memiliki sedikit akar. Kerutan terlihat pada permukaan umbinya. Retakan pada umbi tidak ditemukan pada umbi tiga varian D.esculenta, namun ditemukan pada varian gembili kemarung. Bentuk umbi varian D.esculenta ditunjukkan pada Gambar 8.

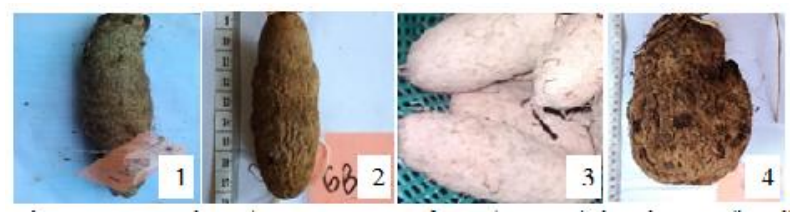

Gambar 8. Bentuk umbi varian D.ecsulenta Keterangan: 1. Gembili pak yasir (kecil) 2.Gembili pak yasir 3. Gembili biasa 4. Gembili kemarung

Umbi varian D.esculenta memiliki kulit tipis dan bertekstur halus. Umbi gembili kemarung memiliki kulit yang tebal dan bertekstur kasar. Kulit luar umbi varian umbi D.esculenta umumnya beerwarna coklat muda, kecuali gembili biasa yang kulit luarnya berwarna krem. Kulit dalam umbi D.esculenta berwarna krem, kecuali gembili kemarung yang kulit dalam umbinya berwarna coklat muda.

Daging umbi varian D.esculenta umumnya berwarna putih susu, kecuali gembili kemarung yang daging umbinya berwarna krem. Tekstur daging umbi keempat varian D.esculenta bervariasi dari halus sampai sangat kasar. Daging umbi gembili biasa bertekstur halus. Daging umbi gembili p yasir (kecil) bertekstur halus agak kenyal. Daging umbi gembili kemarung bertekstur kasar dan daging umbi gembili $\mathrm{p}$ yasir bertekstur sangat kasar. Warna daging umbi varian D.esculenta ditunjukkan pada Gambar 9.

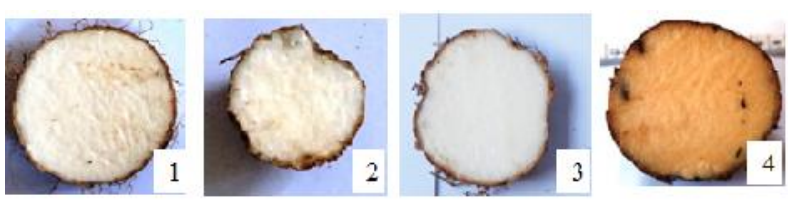

Gambar 9. Warna daging umbi varian $D$. esulenta

Keterangan: (1. Gembili pak yasir (kecil) 2. Gembili pak yasir 3. Gembili biasa 4. Gembili kemarung)

Menurut Suranto (2001) perbedaan bentuk, ukuran dan warna daging pada varian uwi dapat disebabkan oleh faktor lingkungan. Tanaman sejenis akan bervariasi morfologinya apabila faktor lingkungan lebih dominan mempengaruhi tanaman dari pada faktor genetik. Tanaman tidak akan menunjukan variasi morfologi yang signifikan apabila faktor genetik lebih dominan mempengaruhi tanaman tersebut.

\section{KESIMPULAN}

1. Berdasarkan hasil identifikasi, uwi pandan, uwi wulung, uwi bangkulit dan uwi putih termasuk ke dalam jenis D.alata. Gembili p yasir (kecil), gembili p yasir, gembili biasa, dan kemarung termasuk ke dalam jenis D. esculenta.

2. Berdasarkan hasil karakterisasi morfologi batang dan daun, jenis $D$. alata dan $D$. esculenta dibedakan oleh karakter arah putaran batang, bentuk daun, ada tidaknya duri, ada tidaknya sayap dan ada tidaknya umbi udara. Varian $D$. alata dibedakan oleh karakter warna batang, warna sayap, warna tepi daun, warna tulang daun, warna tangkai daun, warna sayap tangkai daun, warna ujung daun, dan undulasi daun. Varian D. esculenta dibedakan oleh karakter warna batang, bentuk duri, warna daun, warna tepi daun, warna dan tulang daun.

3. Berdasarkan hasil karakterisasi ciri morfologi umbi jenis $D$. alata dan $D$. esculenta dibedakan oleh karakter jumlah umbi per 'hill', bentuk umbi, dan adanya kerutan pada permukaan umbi. Varian D. alata dibedakan oleh karakter bentuk umbi, warna daging umbi, tekstur daging, warna kulit luar dan kulit dalam umbi, ketebalan kulit, retakan dan akar pada umbi. Varian D. esculenta dibedakan oleh karakter warna dan tekstur daging umbi, warna kulit luar dan kulit dalam umbi, tekstur kulit luar, 
ketebalan kulit, kerutan, retakan dan akar pada umbi.

\section{DAFTAR PUSTAKA}

Ariesta, K. 2004. Umbi-Umbian Berjasa yang Terlupa. Simpul Pangan Jogjakarta.Yayasan KEHATI, Jogjakarta.

Arifin Z. 2008. Diversifikasi Dioscorea Flour sebagai Sumber Alternatif Pangan.

Biological Fair ITS. Surabaya.

Budoyo S.,2010. Kandungan Karbohidrat dan Pola Pita Isozim Pada Varietas Lokal Ubi Kelapa (Dioscorea alata L.) di Kabupaten Karanganyar.TESIS

Cahyarini, R.D, Ahmad Y. dan Edi P. 2004. Identifikasi Keragaman genetik Beberapa Varietas Lokal Kedelai di Jawa Berdasarkan Analisis Isozim. TESIS. Program Pasca Sarjana. Universitas Sebelas Maret Surakarta.

French, B.R. 2006. Food plants of Papua New Guinea. A compendium. Privately published as an electronic book in pdf format. Downloaded at: http://papuaweb.org/dlib/bk/french/

Hanarida, I, M. Hasanah \& H. Kurniawan. 2005. Teknik Konservasi Ex Situ Rejuvinasi, Karakterisasi, Evaluasi, Dokumentasi, dan Pemanfaatan Plasma Nutfah. Balai Besar Penelitian Dan Pengembangan Bioteknologi. Bogor. Bogor.

IPGRI/IITA. 1997. Descriptors for Yam (Dioscorea spp.). International Institute of Tropical Agriculture, Ibadan, Nigeria/International Plant Genetic Resources Institute. Rome, Italy.

Jumari dan S.W. Agung Suedy. 2017. The Diversity of Dioscorea spp. In Central Java Inonesia : Local utilization and Conservation. Advanced Science Letters, American Scientific Journals Volume 23, Number 7, July 2017, pp. 6441-6443 (3).

Mirza MS. 2005. Pengujian beberapa taraf tinggi lanjaran terhadap pertumbuhan dan produktivitas Dioscorea esculenta (Lour.) Burk. (Combilium) SKRIPSI Bogor (ID): Institut Pertanian Bogor.
Richana, N. Sunarti T.C., 2004, Karakterisasi sifat fisikokimia tepung umbi dan

tepung pati dari umbi ganyong, suweg, ubi kelapa dan gembili, J. Pascapanen 1 (1) : 29-37.

Suranto. 2001. Study on Ranunculus population: isozymic pattern. Biodiversitas 2(1): 85-91.

Wilson, Jill E. 1988. A Practical Guide To Identifying Yams: The Main Species of Dioscorea In The Pacific Islands. IRETA Publications USP Alafua Campus PO. Private Bag Apia. West Samoa. 
Karakterisasi uwi uwian 
Bioma, Desember 2018

p ISSN: $1410-8801$

Vol. 20, No. 2, Hal. 92-99

e ISSN: 2598-2370 